\title{
The volcano rabbit- a shrinking distribution and a threatened habitat
}

\author{
J. Hoth, A. Velazquez, F. J. Romero, L. Leon, M. Aranda and D. J. Bell
}

The first systematic search for the volcano rabbit, a Mexican endemic, found no evidence of the species outside the central region of the transverse neovolcanic axis around Mexico City, and reveals that the rabbit has now disappeared from areas of this central zone where it has been reported in the recent past. It depends for its survival on the pine forest-bunch grass ecosystem, and this is being destroyed by conversion to agriculture, over-grazing, fire-burns, poor forestry management and encroaching property developments. The authors make recommendations for the immediate protection of the remaining areas of core habitat and for further research.

The volcano rabbit, or 'zacatuche', Romerolagus diazi is believed to be amongst the most primitive of the living species of rabbits and hares $(O$. Lagomorpha; Family: Leporidae) (De Poorter and Van der Loo, 1981; Corbet, 1983; Barrera, 1966).

Prior to the present study no systematic search for this Mexican endemic had ever been carried out, yet its distribution is repeatedly described as being restricted to scattered areas of sub-alpine pine'zacaton' (bunch grass) and alder-'zacaton' forest at altitudes of $2650-4250 \mathrm{~m}$ on the slopes of three volcanic sierras close to Mexico City (Granados, 1981; Cervantes, 1980) in an area of approximately $150 \mathrm{sq} \mathrm{km}$ (Lopez-Forment and Cervantes, 1979). These sierras-namely the Ajusco, Sierra Nevada (IztaccihuatlPopocatepetl) and Nevado de Toluca Rangesform part of the transverse neovolcanic axis, which spans the approximately $1000 \mathrm{~km}$ breadth of central Mexico between $18^{\circ}$ and $22^{\circ} \mathrm{N}$.

The rapid destruction of its habitat, together with its continued hunting, have been identified as the major threats to the future survival of the species. The restricted areas of zacaton/forest habitat are being continually eroded by a combination of encroaching agriculture, sprawling urbanization, The volcano rabbit the uncontrolled burning of 'zacaton' grasses to promote new growth of grazing pasture for cattle and sheep, plus the exploitation of zacaton for the manufacture of household brushes (Thornback and Jenkins, 1982; Granados, 1981). The aims of the present study were, firstly, to characterize the habitat of known populations of $R$. diazi in terms of altitude, temperature, climate and dominant vegetation types, and secondly, to conduct an extensive search for the species in these and other areas of equivalent habitat across the entire transverse neovolcanic axis.

\section{The transverse neovolcanic axis (TNA)}

Biogeographically, the TNA lies within a zone of transition between nearctic and neotropical regions. The TNA has its origins in several phases of volcanic activity that occurred during the Cenozoic, but its highest peaks date from the Pliocene/Quaternary period (Demant, 1978). These include the Pico de Orizaba $(5700 \mathrm{~m}) *$, Popocatepetl $(5540 \mathrm{~m})$, Iztaccihuatl $(5220 \mathrm{~m})$, Nevado de Toluca (4680 m), Malinche (4461 m), the Colima volcanoes ( 4240 and $4220 \mathrm{~m}$ ), Cofre de Perote $(4281 \mathrm{~m})$ and Tancitaro (3845 $\mathrm{m})$.

*Altitudes from Aspectos Geograficos, 1, 34-35 (Secretaria de Programacion y Presupuesta, 1981). 
A temperate type climate prevails over the entire length of this volcanic range, with a rainy season during the hottest period of the year. The principal soil types are derived from volcanic ash or the weathering of volcanic rocks (Clausen, 1959). Together, these climatic and edaphic features appear to favour the establishment of forests co-dominated by Pinus montezumae, $P$. pseudostrobus, $P$. rudis and $P$. teocote. At altitudes more than $3000 \mathrm{~m}$ above sea-level forests of $P$. hartwegii and Abies religiosa in association with Festuca, Calamagrostis, Muhlenbergia agrostis and Stipa bunch grass genera predominate (Rzedowski, 1983).

The existence of several plant and animal species endemic to the TNA may be attributable to the influence of a number of interacting physiographic features, for example the TNA's scattered distribution as isolated volcanic 'islands', and the probable altitudinal and longitudinal displacement of vegetation types during the glacial and interglacial periods (Moore, 1945; Rzedowski, 1983; Ceballos and Galindol, 1984; Flenley, 1979).

\section{Methods}

\section{Habitat characterization}

A list of the 31 sites with accurate map references where the species had been previously reported* was collated. These sites were located on topographical maps (Scale 1: 1,000,000 m) and the resulting zones of 'reported distribution' for the species then characterized in terms of maximum and minimum altitude, temperature range and dominant climatic and vegetation types $\dagger$.

This analysis revealed the following:

(a) 87 per cent of $R$. diazi records had been collected at altitudes of between $3000 \mathrm{~m}$ and $4000 \mathrm{~m}$ above sea-level;

(b) 87 per cent of these reports occurred in areas climatically characterized as 'semi-cold, sub-

*Compiled from Rojas (1951), Ramirez-Pulido (1969), Cervantes (1980) and the Mammal Collection at the Instituto de Biologia, UNAM.

$\uparrow$ All analyses used appropriate (climate, temperature, altitude and vegetation) maps produced by the Direccion General de Geografia, of the Secretaria de Programacion y Presupuesto (SPP).

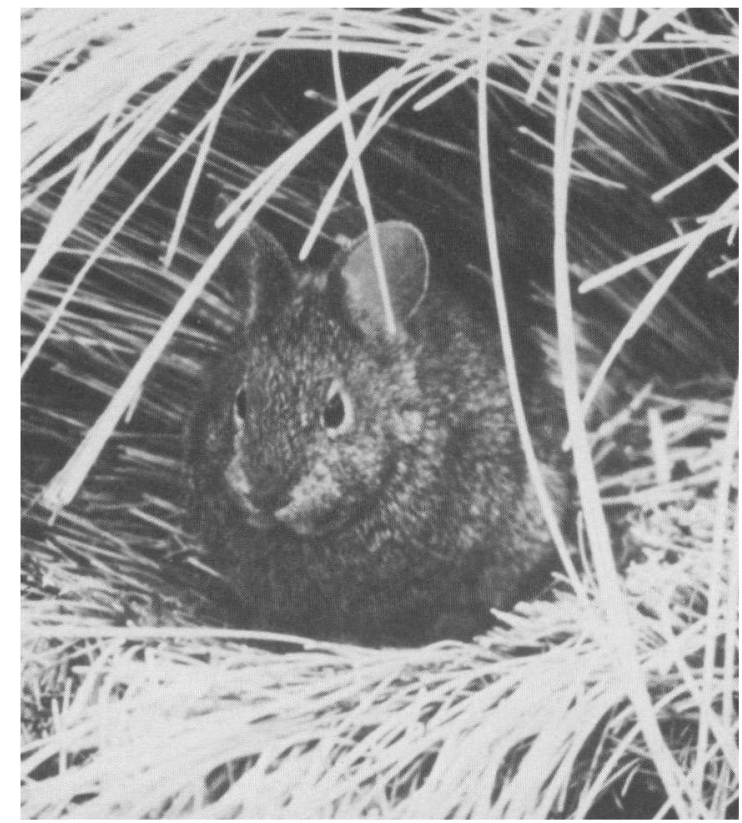

Volcano rabbit sheltering beneath zacaton bunch grass (Diana Bell).

humid and humid with abundant rainfall in summer';

(c) the vegetation at 97 per cent of these sites was identified as Pinus forest associated with forests of Abies.

Further cartographical extrapolation of these range data identified eight other areas (covering a total of approximately 463,400 ha) within the TNA that showed similar vegetational, climatic and altitudinal profiles to the above 'reported distribution' zone (Figures 1 and 2).

\section{Distribution survey}

The central TNA zone of 'reported distribution' and areas of equivalent habitat listed in Figure 2 were surveyed using a combination of direct search (transect walks) and interviewing techniques. During transect walks, any signs (faecal pellets, tracks) of lagomorph species were recorded, together with general observations of habitat status, for example evidence of recent fire-burns and disease infestation of the forest. Vegetation samples were also collected for later identification. Three species of Sylvilagus also occur across the TNA. Sylvilagus floridanus (the

Oryx Vol 21 No 2, April 1987 


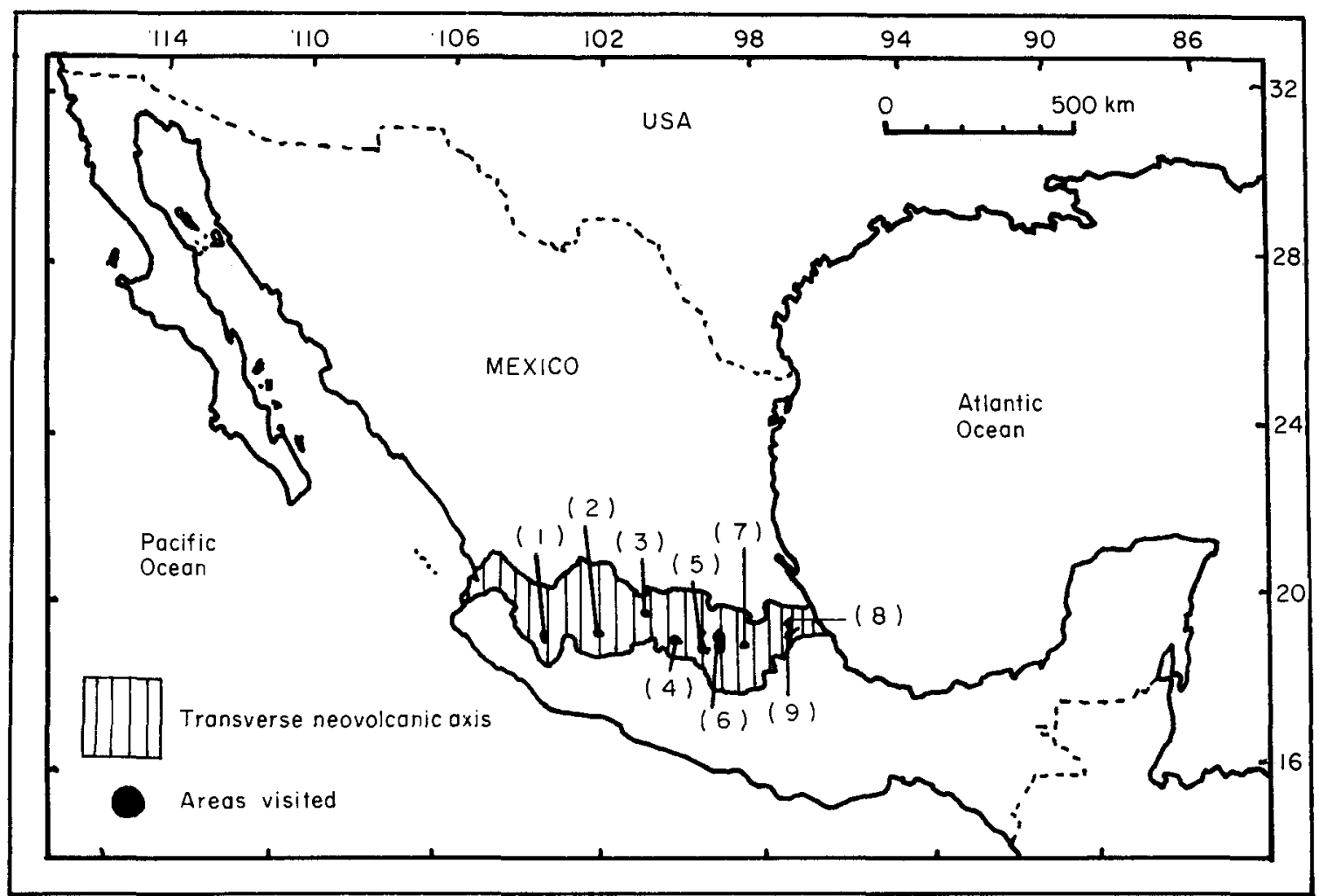

Figure 1. TNA areas visited (from west to east): (1) Nevado de Colima; (2) Tancitaro; (3) Sierra Chincua;

(4) Nevado de Toluca; (5) Sierras Chichinautzin and Ajusco; (6) Sierra Nevada

(Iztaccihuatl-Popocatept]); (7) Malinche; (8) Cofre de Perote; (9) Pico

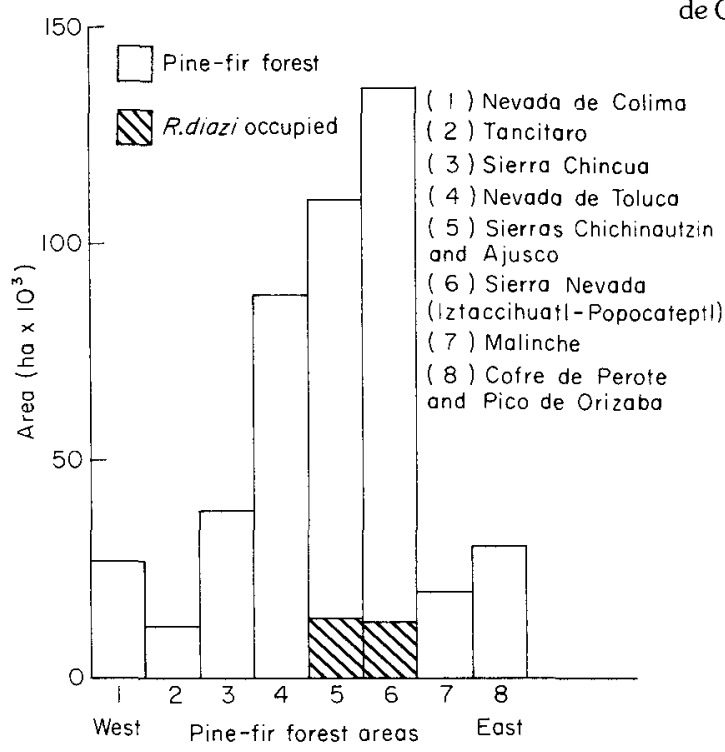

Figure 2. Distribution of areas of pine-fir forest habitat (potential $R$. diazi areas) across the TNA.

The volcano rabbit eastern cottontail) and $S$. cunicularis (the Mexican cottontail) are readily distinguished from $R$. diazi by their larger body size, longer ears and their possession of a white tail. Sylvilagus brasiliensis (the forest rabbit), whose distribution crosses the eastern edge of the TNA, can be distinguished on the basis of its larger size, reddish dorsal coat, short ears and absence of a white tail.

Faecal pellets produced by $S$. floridanus, $S$. cunicularis and $R$. diazi may be discriminated on the basis of relative size and shape. Those produced by the latter two species have a flattened appearance in transverse section and are more uniformly rounded in appearance when viewed from above. This contrasts with the more irregular shape (often pointed at one end) of S. floridanus pellets, which also tend to be intermediate in size between those of $S$. cunicularis and $R$. diazi. Tracks left by $R$. diazi can also be distinguished by their smaller dimensions (Aranda, 1981). 

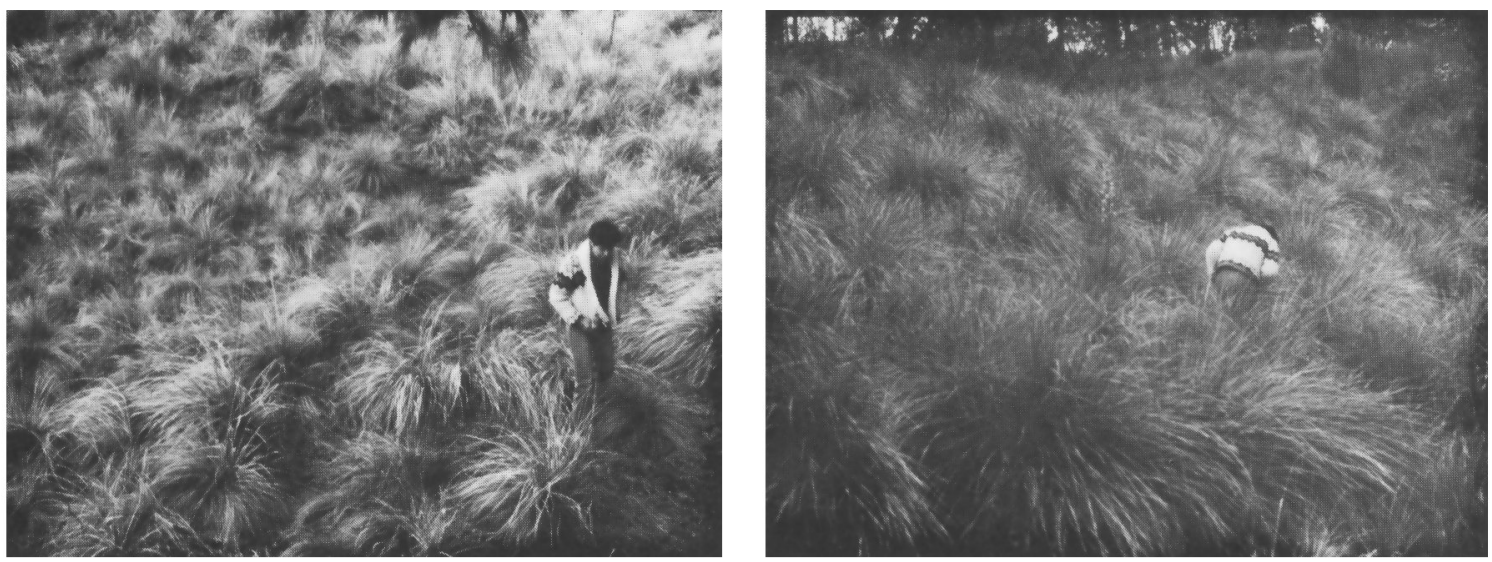

Poor (left) and good (right) cover zacaton at $3010 \mathrm{~m}$ and $3200 \mathrm{~m}$, respectively, V. Pelado (Diana Bell).

Interviews involved the informal questioning of local people, for example hunters, campesinos, forestry officers, about the lagomorphs present in that area.

\section{Results and discussion}

These surveys found no evidence of the volcano rabbit in zones of comparable habitat on any of those volcanoes to the east or west of the central TNA zone of known distribution (Table 1). The survey findings also suggest that the species has disappeared from large areas of the central TNA zone where it had been reported in the past, for example the eastern slopes of Iztaccihuatl (Rojas, 1951) and the Nevado de Toluca. Local inhabitants from the latter area claimed that these rabbits disappeared some 15-20 years ago.

Both these central zone areas and the peripheral TNA volcanoes showed signs of considerable habitat degradation (Table 1). These signs include soil erosion, thin ground-cover by zacaton grasses (and generally thin cover by several vegetational strata) together with forest infestation by bark beetle pest (Dendroctonus spp.) and parasitic mistletoe (Arceuthobium spp.). Infestation with bark beetle and mistletoe was particularly prevalent around the Nevado de Toluca and eastern slopes of Iztaccihuatl, for example.

A number of agents appear to be responsible for the continuing erosion of the forest-zacaton habitat across the TNA. These include forest fires, 88 over-grazing of zacaton by cattle and sheep, overexploitation of timber (i.e. poor/non-existent forestry management), encroachment by agriculture and property developments, and the exploitation of zacaton grasses for brushes and thatch.

The present survey identified forest fires in combination with over-grazing by livestock as the major agents of habitat destruction. Posters produced by the Forestry Division in the present campaign to reduce the incidence of forest fires warn that 98 per cent of such fires are started by man. Many of these originate from the uncontrolled burning of zacaton to promote new growth of grazing pasture for cattle and sheep.

Wholesale clearance of zacaton for the planting of agricultural crops is also widespread, with different regions specializing in particular crops. Potato is the principal crop around the eastern volcanoes-Cofre de Perote and Pico de Orizaba, for example, while late-ripening avocados have already recently replaced maize as a more lucrative crop on the slopes of $V$. Tancitaro.

Within the central TNA zone, the three largest areas of habitat occupied by $R$. diazi were located on the slopes of the four volcanoes, namely Popocatepetl/Iztaccihuatl (Sierra Nevada), El Pelado and Tlaloc (Sierra de Chichinautzin, south of the Sierra del Ajusco) and measured approximately 14,600, 4800 and 8600 ha, respectively 
(Figure 3). This total area of approximately 28,000 ha or $280 \mathrm{sq} \mathrm{km}$ represents an area of occupied habitat nearly twice the size of that reported by previous workers. These areas are discontinuous: Volcan Tlaloc is situated $40 \mathrm{~km}$ west of Popocatepetl, and V. Pelado lies $20 \mathrm{~km}$ west of V. Tlaloc. The scattered distribution of volcano rabbit populations within these core areas appears to be related to the density of zacaton grass ground-cover. Observations of captive individuals at Chapultepec Zoo suggest that dense zacaton cover may provide the rabbits

Table 1. Results of $R$. diazi survey in areas of pine-fir/zacaton habitat across the TNA

\begin{tabular}{|c|c|c|}
\hline Volcano & Conclusions & Status of forest-zacaton habitat \\
\hline $\begin{array}{l}\text { Peripheral TNA areas } \\
\text { Pico de Orizaba }\end{array}$ & $\begin{array}{l}\text { No R. diazi. } \\
\text { Sylvilagus spp. } \\
\text { present, including } \\
\text { S. brasiliensis }\end{array}$ & $\begin{array}{l}\text { Interviewees reported that the areas of 'good' zacaton were eliminated by } \\
\text { approximately } 50 \text { years of exploitation for the manufacture of household } \\
\text { brushes. The factory concerned moved to the Nevado de Toluca area } \\
2-3 \text { years ago to continue its work. } \\
\text { Abies spp. are extracted for paper production. One timber factory was } \\
\text { recently closed because of its over-exploitation practices. } \\
\text { Agricultural encroachment: principal crops are potato, maize and wheat. } \\
\text { Generally poor ground cover by remaining zacaton. One small area with } \\
\text { 'good' cover zacaton. }\end{array}$ \\
\hline Cofre de Perote & $\begin{array}{l}\text { No } R \text {. diazi. } \\
\text { Syluilagus spp. } \\
\text { present }\end{array}$ & $\begin{array}{l}\text { Extremely impoverished. } \\
\text { Evidence of extensive soil erosion resulting from a combination of fire } \\
\text { burns, over-grazing and poorly managed timber exploitation. Areas of } \\
60 \text { per cent bare soil cover at } 2700 \mathrm{~m} \text { where re-afforestation } \\
\text { programmes are in progress. } \\
\text { Forest infestation with mistletoe. } \\
\text { Agricultural encroachment-predominantly potato. }\end{array}$ \\
\hline La Malinche & $\begin{array}{l}\text { No } R \text {. diazi. } \\
\text { Sylvilagus spp. } \\
\text { present }\end{array}$ & $\begin{array}{l}\text { Extensive agricultural encroachment and grazing of zacaton by sheep } \\
\text { and cattle. } \\
\text { Campesinos burn to promote new growth of zacaton. } \\
\text { Generally poor cover zacaton with small area of } \\
\text { good zacaton around the 'auberge'. }\end{array}$ \\
\hline Nevado de Colima & $\begin{array}{l}\text { No R. diazi. } \\
\text { Sylvilagus spp. } \\
\text { present }\end{array}$ & $\begin{array}{l}\text { Evidence of considerable over-grazing by cattle, together with } \\
\text { uncontrolled burning of zacaton. } \\
\text { Bark beetle and mistletoe infestation of forest. } \\
\text { Only two areas of 'good' zacaton encountered of } 500 \mathrm{sq} \mathrm{m} \text { and } 1 \mathrm{~km} \\
\times 500 \mathrm{~m} \text {, respectively (where Sylvilagus spp. were found). }\end{array}$ \\
\hline Volcan de Tancitaro & $\begin{array}{l}\text { No } R \text {. diazi. } \\
\text { Sylvilagus spp. } \\
\text { present }\end{array}$ & $\begin{array}{l}\text { Few pockets of zacaton remain. Zacaton is burned for cattle grazing and } \\
\text { there has been considerable agricultural encroachment. }\end{array}$ \\
\hline Sierra Chincua & No $R$. diazi. & - \\
\hline $\begin{array}{l}\text { Central TNA zone } \\
\text { Sierra Nevada } \\
\text { (Popocatepetl and } \\
\text { lztaccihautl) }\end{array}$ & $\begin{array}{l}\text { R. diazi and } \\
\text { Sylvilagus spp. } \\
\text { present }\end{array}$ & $\begin{array}{l}\text { Ongoing encroachment by property developments and poor } \\
\text { management of National Parks where } R \text {. diazi occurs. } \\
\text { Frequent illegal activities in these parks include hunting, cattle grazing and } \\
\text { related forest fires. }\end{array}$ \\
\hline $\begin{array}{l}\text { Sierra Chichinautzin } \\
\text { (Tlaloc and Pelado) }\end{array}$ & $\begin{array}{l}\text { R. diazi and } \\
\text { Sylvilagus spp. } \\
\text { present }\end{array}$ & $\begin{array}{l}\text { Adequate forestry management and close vigilance of forest fires. } \\
\text { Best represented forest-zacaton habitat in entire TNA. } \\
\text { Scattered agricultural encroachment (mainly oats). } \\
\text { Frequent forest fires and hunting, and the zacaton grasses are used } \\
\text { locally for thatch. }\end{array}$ \\
\hline
\end{tabular}


with secure refuge and nesting sites (Hoth, in prep. ). It is important to emphasize that scattered, small populations of $\mathrm{R}$. diazi (covering a total of approximately 1000 ha) were found outside these three core areas, separated from the latter by physical barriers such as free-ways and contrasting habitat. The small size and isolated distribution of these peripheral populations make them highly vulnerable.

Each of the agents of habitat erosion listed earlier also continues to operate within these remaining core areas. All three areas remain under constant threat from uncontrolled forest fires, and evidence of extensive recent fire burns was recorded during brief visits to the $V$. Pelado and $\mathrm{V}$. Tlaloc areas in April 1985. The numerous charred faecal pellets of $R$. diazi found scattered between the clumps of burned zacaton provided evidence of recently viable populations of the species. In the V. Pelado area we also recorded cattle grazing on recently burned zacaton, forest infestation by bark beetle and the cutting of zacaton grasses (Muhlenbergia spp.) for thatch. In the Popocatepetl area, 1200 ha of prime zacaton/ forest habitat around Cerro Gordo is currently being sold off in 750 -sq-m lots by property

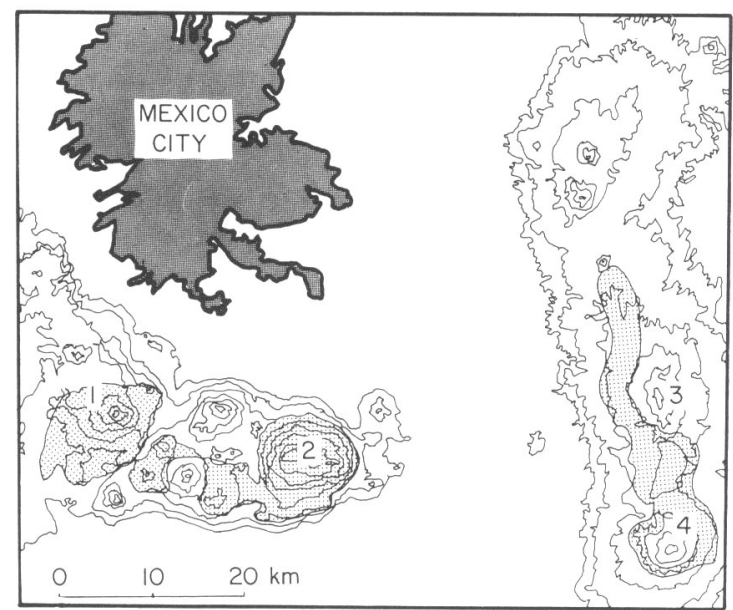

Figure 3. Present distribution of Romerolagus diazi (stippled areas). (1) V. Pelado; (2) V. Tlaloc; (3 and 4) Sierra Nevada.

developers. Land prices are low and a number of holiday homes have already been built on the site. We were also told of plans for an accompanying cable-car development, which would similarly exacerbate the encroaching tourist developments around Popo. Hunting represents a further threat to the survival of the

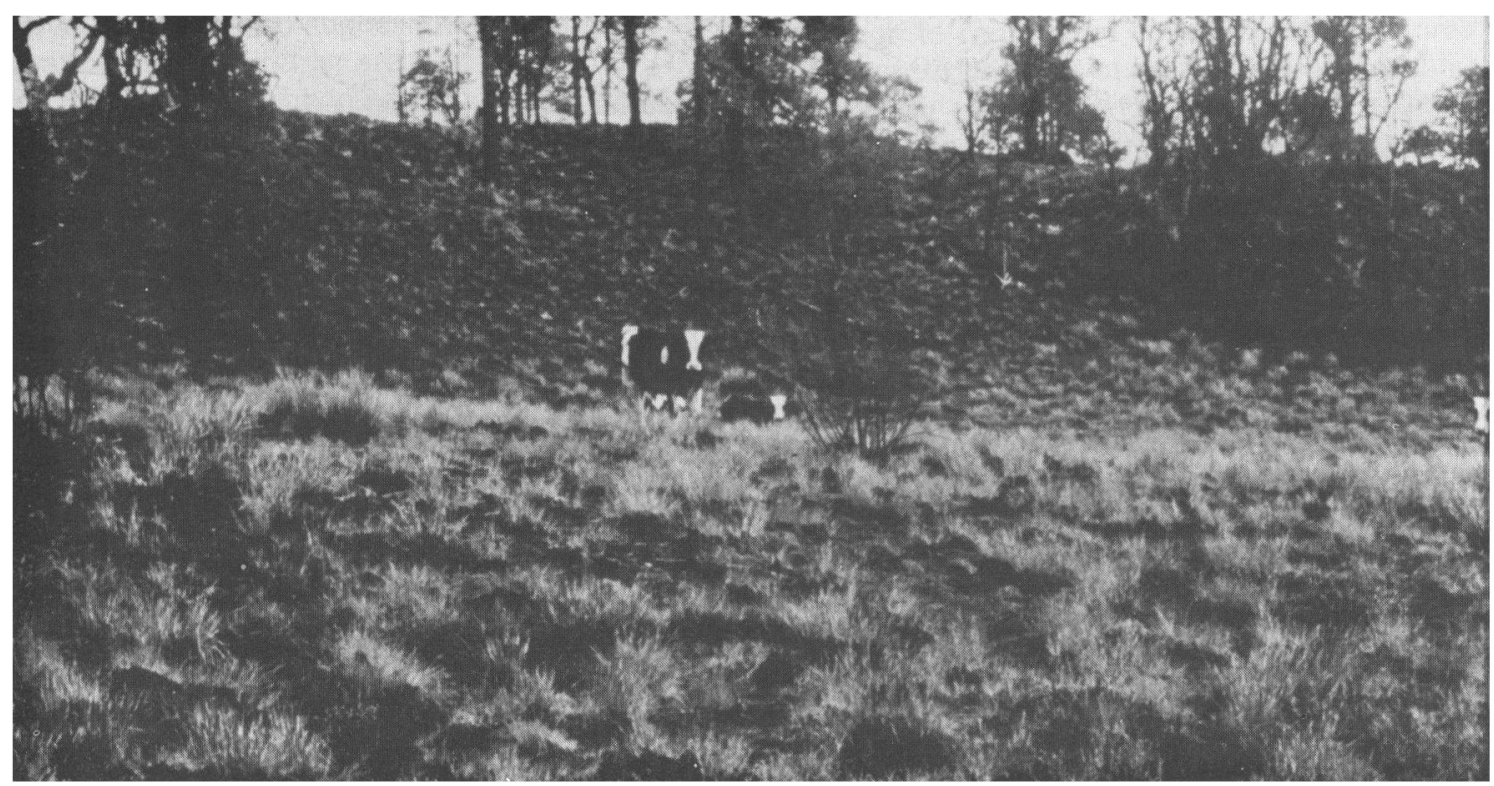

Cattle grazing on new growth zacaton grasses following fireburn, V. Pelado (Diana Bell). 
species in each of the above areas. Although the hunting of $R$. diazi is now illegal, the legislation is not enforced.

\section{Recommendations}

The results of the present survey of $R$. diazi highlight the importance of three core areas of subalpine zacaton/forest habitat associated with the central TNA volcanoes Popocatepet//Iztaccihuatl (Sierra Nevada), El Pelado and Tlaloc (Sierra de Chichinautzin). These three remaining core areas of habitat occupied by $R$. diazi cover a total of approximately 28,000 ha. These areas require some form of immediate protection if the species is to survive in the wild. In order to formulate appropriate management plans for this habitat further research is urgently required in each of the following areas:

(i) the dynamics of the zacaton-forest vegetation, for example the nature of the vegetational succession and the effects of livestock grazing/ fire-burns on the vegetation;

(ii) the relationship between the rabbit and its zacaton-forest habitat, for example its feeding ecology and zacaton requirements for refuge/ nesting;

(iii) the population dynamics and social organization of $R$. diazi (mortality factors, size of home-range and breeding groups);

(iv) the evolutionary history of $R$. diazi: how long has its distribution been so restricted? Has it always shown this exclusive relationship with subalpine pine forest-zacaton habitat?

Investigations into the fossil history of the species and the previous botanical profiles (by pollen analysis) of these areas are required.

\section{Acknowledgments}

We are indebted to Wildlife Preservation Trust International and The British Council for their financial support of this project. Jersey Wildlife Preservation Trust and Ramon Perezgil similarly provided invaluable support throughout this work.

\section{References}

Aranda, S.J. 1981. Rastros de los Mamiferos Silvestres de Mexico. Manual de Campo. INIREB, Mexico.

Barrera, A. 1966. Redefinicion de Cediopsylla Jordan y Hoplopsyllus Baker. Nuevas especies, comentarios sobre

The volcano rabbit el concepto de relicto y un caso de evolucion convergente. Rev. Soc. Mex. Hist. Nat. XXVII, 67-83.

Ceballos, G.G. and Galindol, C. 1984. Mamiferos Silvestres de la Cuenca de Mexico. Limusa. Mexico.

Cervantes, R.F. 1980. Principales caracteristicas biologicas del conejo de los volcanes Romerolagus diazi FerrariPerez, 1983) (Mammalia: Lagomorpha). Unpubl. Tesis Biologo. Facultad de Ciencias, UNAM, Mexico, DF.

Clausen, R.F. 1959. Geology of the Trans-Mexican Volcanic Belt. In: Sedum of the Trans-Mexican Volcanic Belt: An exposition of taxonomic methods. Cansford Publ, Ithaca, NY.

Corbet, G.B. 1983. A review of classification in the family Leporidae. Acta Zool. Fennica, 174, 11-15.

Demant, A. 1978. Caracteristicas del Eje Neovolcanico Transmexicano y sus problemas de interpretacion. Universidad Nacional Autonoma de Mexico, Instituto de Geologia, Revista, 2, 172-187.

De Poorter, M. and Van der Loo, W. 1981. Report on the breeding and behaviour of the volcano rabbit at the Antwerp Zoo. In: Proceedings of the World Lagomorph Conference, Guelph 1979 (Eds K. Myers and C.A. MacInnes). University of Guelph.

Flenley, J.R. 1979. The late Quaternary vegetational history of the equatorial mountains. Progr. Phys. Geog. 3, 488509.

Granados, H. 1981. Basic information on the volcano rabbit. In: Proceedings of the World Lagomorph Conference, Guelph 1979 (Eds K. Myers and C.A. MacInnes). University of Guelph.

Lopez-Forment, W. and Cervantes, F. 1979. Preliminary observations of the ecology of Romerolagus diazi in Mexico. In: Proceedings of the World Lagomorph Conference, Guelph, 1979 (Eds K. Myers and C.A. MacInnes). University of Guelph.

Moore, T.R. 1945. The transverse volcanic biotic province of central Mexico and its relationship to adjacent provinces. Trans. San Diego Soc. Nat. Hist. 10, 217-236.

Ramirez-Pulido, J. 1969. Contribucion estudio de los mamiferos de Parque Nacional 'Lagunas de Zempoala', Mexico. An. Inst. Biol. UNAM 40 Ser. Zool. 1, 253-290.

Rojas, M.P. 1951. Estudio biologico del conejo de los volcanes (Genero Romerolagus) (Mammalia; Lagomorpha). Unpubl. Tesis. Professional Biologia. Facultad de Ciencias, UNAM, Mexico.

Rzedowski, J. 1983. Vegetacion de Mexico. Limusa. Mexico. SPP (Secretaria de Programacion y Presupuesto) 1981. Mexico: Informacion sobre aspectos geograficos, sociales y economicos. Volumen 1, Mexico.

Thornback, J and Jenkins, M. 1982. The IUCN Mammal Red Data Book Part 1. IUCN, Gland, Switzerland.

J. Hoth, A. Velazquez and F. J. Romero, Laboratorio de Biogeografia, Departamento de Biologia, Facultad de Ciencias. UNAM, Mexico DF 04510.

L. Leon, Museo de Zoologia, Facultad de Ciencias, UNAM 70-399, Mexico DF 04510.

M. Aranda, INIREB Chiapas, San Cristobal de las Casas, Chiapas, Mexico.

D.J. Bell, School of Biological Sciences, University of East Anglia, Norwich, Norfolk NR4 7TJ, UK (to whom reprint requests should be sent). 